\title{
Directory of online tables
}

The tables listed below are available as Excel spreadsheets via weblinks accessible from the main Economic \& Labour Market Review (ELMR) page of the National Statistics website. Tables in sections 1, 3, 4 and 5 replace equivalent ones formerly published in Economic Trends, although there are one or two new tables here; others have been expanded to include, as appropriate, both unadjusted/seasonally adjusted, and current price/chained volume measure variants. Tables in sections 2 and 6 were formerly in Labour Market Trends. The opportunity has also been taken to extend the range of dates shown in many cases, as the online tables are not constrained by page size.

In the online tables, the four-character identification codes at the top of each data column correspond to the ONS reference for that series on our time series database. The latest data sets for the old Economic Trends tables and the Labour Market Statistics First Release tables are still available on this database via the 'Time Series Data' link on the National Statistics main web page. These data sets can also be accessed from links at the bottom of each section's table listings via the 'Data tables' link in the individual ELMR edition pages on the website.

Weblink: www.statistics.gov.uk/elmr_tables

Title

Frequency of update

Updated since last month

\section{UK economic accounts}

1.01 National accounts aggregates

1.02 Gross domestic product and gross national income

1.03 Gross domestic product, by category of expenditure

1.04 Gross domestic product, by category of income

1.05 Gross domestic product and shares of income and expenditure

1.06 Income, product and spending per head

1.07 Households' disposable income and consumption

1.08 Household final consumption expenditure

1.09 Gross fixed capital formation

1.10 Gross value added, by category of output

1.11 Gross value added, by category of output: service industries

1.12 Summary capital accounts and net lending/net borrowing

1.13 Private non-financial corporations: allocation of primary income account

1.14 Private non-financial corporations: secondary distribution of income account and capital account

1.15 Balance of payments: current account

1.16 Trade in goods (on a balance of payments basis)

1.17 Measures of variability of selected economic series

1.18 Index of services

M
$M$
$M$
$M$
$M$
$Q$
$M$
$M$
$M$
$M$
$M$
$Q$
Q
Q
$M$
$M$
Q

\section{Selected labour market statistics}

2.01 Summary of Labour Force Survey data

2.02 Employment by age

2.03 Full-time, part-time and temporary workers

2.04 Public and private sector employment

2.05 Workforce jobs

2.06 Workforce jobs by industry

2.07 Actual weekly hours of work

2.08 Usual weekly hours of work

2.09 Unemployment by age and duration

2.10 Claimant count levels and rates

2.11 Claimant count by age and duration

2.12 Economic activity by age

2.13 Economic inactivity by age

2.14 Economic inactivity: reasons

2.15 Educational status, economic activity and inactivity of young people

$M$
$M$
$M$
$M$
$M$
$M$
$M$
$M$
$M$
$Q$
$Q$
$M$
$M$
$M$

2.16 Average earnings - including bonuses

2.17 Average earnings - excluding bonuses

2.18 Productivity and unit wage costs

2.19 Regional labour market summary

\begin{tabular}{cc}
$M$ & $v$ \\
$M$ & $v$ \\
$M$ & $v$ \\
\hline & $\cdot$ \\
$Q$ & $\cdot$ \\
$Q$ & $v$ \\
$M$ & $v$ \\
$M$ & $v$ \\
$M$ & $v$ \\
$M$ & $v$ \\
$M$ & $v$ \\
$M$ & $v$ \\
$M$ & $v$ \\
$M$ & $v$ \\
$M$ & $v$ \\
$M$ & $v$ \\
$M$ & $v$ \\
$M$ & $v$ \\
$M$ &
\end{tabular}


Weblink: www.statistics.gov.uk/elmr_tables

2.20 International comparisons

$\mathrm{M}$

2.21 Labour disputes

2.22 Vacancies

2.23 Vacancies by industry

2.24 Redundancies: levels and rates

2.25 Redundancies: by industry

2.26 Sampling variability for headline labour market statistics
M

$\mathrm{M}$

$\mathrm{M}$

$\mathrm{M}$

Q

$\mathrm{M}$

\section{Prices}

3.01 Producer and consumer prices

3.02 Harmonised Indices of Consumer Prices: EU comparisons

M

\section{Selected output and demand indicators}

4.01 Output of the production industries

4.02 Engineering and construction: output and orders

4.03 Motor vehicle and steel production

4.04 Indicators of fixed investment in dwellings

4.05 Number of property transactions

4.06 Change in inventories

4.07 Inventory ratios

4.08 Retail sales, new registrations of cars and credit business

4.09 Inland energy consumption: primary fuel input basis

2

\section{Selected financial statistics}

5.01 Sterling exchange rates and UK reserves

5.02 Monetary aggregates

$\mathrm{M}$

5.03 Counterparts to changes in money stock M4

5.04 Public sector receipts and expenditure

5.05 Public sector key fiscal indicators

5.06 Consumer credit and other household sector borrowing

5.07 Analysis of bank lending to UK residents

5.08 Interest rates and yields

$M$

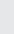

M

M

$\mathrm{M}$

Q

Q

$\mathrm{M}$

M

5.09 A selection of asset prices

\section{Further labour market statistics}

6.01 Working-age households

6.02 Local labour market indicators by unitary and local authority

6.03 Employment by occupation

6.04 Employee jobs by industry

6.05 Employee jobs by industry division, class or group

6.06 Employee jobs by region and industry

6.07 Key productivity measures by industry

6.08 Total workforce hours worked per week

6.09 Total workforce hours worked per week by region and industry group

6.10 Job-related training received by employees

6.11 Unemployment rates by previous occupation

$\mathrm{A}$
$\mathrm{Q}$
$\mathrm{Q}$
$\mathrm{M}$
$\mathrm{Q}$
$\mathrm{Q}$
$\mathrm{Q}$
$\mathrm{Q}$
$\mathrm{Q}$


Weblink: www.statistics.gov.uk/elmr_tables

6.12 Average Earnings Index by industry: excluding and including bonuses

6.13 Average Earnings Index: effect of bonus payments by main industrial sector

M

$M$

6.14 Median earnings and hours by main industrial sector

6.15 Median earnings and hours by industry section

6.16 Index of wages per head: international comparisons

6.17 Regional Jobseeker's Allowance claimant count rates

6.18 Claimant count area statistics: counties, unitary and local authorities

6.19 Claimant count area statistics: UK parliamentary constituencies

6.20 Claimant count area statistics: constituencies of the Scottish Parliament

6.21 Jobseeker's Allowance claimant count flows

6.22 Number of previous Jobseeker's Allowance claims

6.23 Interval between Jobseeker's Allowance claims

6.24 Average duration of Jobseeker's Allowance claims by age

6.25 Vacancies by size of enterprise

6.26 Redundancies: re-employment rates

6.27 Redundancies by Government Office Region

6.28 Redundancy rates by industry

6.29 Labour disputes: summary

6.30 Labour disputes: stoppages in progress

$\begin{array}{lc}M & v \\ M & v \\ A & \cdot \\ A & v \\ M & v \\ M & v \\ M & v \\ M & v \\ M & v \\ M & v \\ Q & \cdot \\ Q & \cdot \\ M & v \\ Q & \cdot \\ Q & \cdot \\ Q & v \\ M & v \\ M & v\end{array}$

\section{Notes}

A Annually

Q Quarterly

M Monthly

\section{More information}

Time series are available from www.statistics.gov.uk/statbase/tsdintro.asp

Subnational labour market data are available from www.statistics.gov.uk/statbase/Product.asp?vlnk=14160 and www.nomisweb.co.uk

Labour Force Survey tables are available from www.statistics.gov.uk/statbase/Product.asp?vlnk=14365

Annual Survey of Hours and Earnings data are available from www.statistics.gov.uk/StatBase/Product.asp?vlnk=13101 